\title{
Moral Dilemmas and the Environment: The Hebrew Bible and the Literature of Industry
}

\section{David Aberbach, McGill University and Oxford University ${ }^{1}$}

\begin{abstract}
Moral dilemmas are central in the literary genre of protest against the effects of industry, particularly in Romantic literature and "Condition of England" novels. Writers from the time of the Industrial Revolution to the present - William Blake, Elizabeth Gaskell, Charles Dickens, Emile Zola, Henrik Ibsen, Anton Chekhov, T.S. Eliot and John Steinbeck - follow the Bible in presenting environmental pollution and calamity in moral terms, and as a consequence of human agency. Dire implications for the environment are equally evident in literature of national rivalry and the misanthropic tradition.
\end{abstract}

Keywords: The Environment; Literature; Industrial Revolution; Moral Issues; Bible.

$\mathrm{T}$

he idea that natural disaster follows human immorality is deeply imprinted in human psychology, and persistently mirrored in literature, often with direct biblical influence. ${ }^{2}$ Especially since the Industrial Revolution, and even amidst the decline of religious faith and practice, much literature follows the Bible in presenting environmental ruin as an inevitable accompaniment of dehumanization and moral corruption. Writers such as Blake, Wordsworth and Goethe are among the outspoken critics of wrong and immoral environmental policies and may be counted as proto-environmentalists, "unacknowledged legislators of humanity", as Shelley described poets at the end of A Defence of Poetry. ${ }^{3}$ Other writers, too, warn of increasing pollution of air and water, and unhealthy and cruel working conditions. To Elizabeth Gaskell in Mary Barton, ${ }^{4}$ the destruction of the environment by industry is a form of murder, a betrayal of Christian love. Charles Dickens in Hard Times,${ }^{5}$ couples' environmental contamination of the typical industrial town with the moral corruption of heartless industrialists such as Bounderby who abuse their impoverished workers as slave-like "operatives" to be paid so much and worked so much:

... it was a town of machinery and tall chimneys, out of which interminable serpents of smoke trailed themselves for ever...It had a black canal in it, and a river that ran purple with ill-smelling dye...

Dostoyevsky is appalled by urban blight, Thoreau by the encroachments of industry, Ibsen by the coverups protecting vested interests, Zola and D. H. Lawrence by the ecological damage done by mining, Chekhov by deforestation brought about by poverty and ignorance, and Wilfred Owen by the damage to the land in war.

1. Professor David Aberbach is affiliated with the Department of Jewish Studies at McGill University and the Environmental Change Institute at Oxford University.

2. This article is largely based on my forthcoming book, The Environment and Literature of Moral Dilemmas: From Adam to Michael $K$. The Biblical Hebrew translations in this article are my own.

3. Percy Bysshe Shelley, Defence of Poetry (Hoboken, NJ: Bibliobytes, 1821).

4. Elizabeth Gaskell, Mary Barton (London: Chapman and Hall, 1848).

5. Charles Dickens, Hard Times (New York: Harper \& Bros., 1854), specifically chapter 5. 
In much literature depicting factory towns, environmental pollution and moral pollution feed on each other; the factory-generated filth of the water mirrors filthy human behavior. In Kafka's The Trial, ${ }^{6}$ the soot and smoke of the city symbolize - as does the fog in Dickens's Bleak House ${ }^{7}$ - the corruption of Law, whose delays, obfuscations and incompetence bring sickness and suffering. Henrik Ibsen, in $A n$ Enemy of the People, ${ }^{8}$ writes of environmental pollution in hostile tones of the Hebrew prophets, as the outward expression of moral pollution; Friedrich Nietzsche, in the prologue to Thus Spoke Zarathustra, ${ }^{9}$ laments that "man is a polluted sea"; Thomas Hardy, in Tess of the D'Urbervilles, ${ }^{10}$ contrasts the Eden of rural England with the destructive encroachments of industry; and T.S. Eliot too, in The Waste Land, ${ }^{11}$ echoes the prophets, particularly Isaiah and Ezekiel, as well as Arthurian legend, in linking moral and environmental pollution. The Waste Land, written in reaction to the slaughter in World War I, depicts a civilization ruined and traumatized, its moral bankruptcy symbolized by biblical imagery of dead land with its stony rubbish, where there is only "A heap of broken images, where the sun beats, / And the dead tree gives no shelter, the cricket no relief, / And the dry stone no sound of water." Pollution of the Thames "empty bottles, sandwich papers, / Silk handkerchiefs, cardboard boxes, cigarette ends" - signifies a more general moral collapse. ${ }^{12}$

Literature of the polluted industrial world owes much to the Hebrew Bible, in which environmental disaster generally follows moral collapse; the betrayal of the covenant is punished by flood, earthquake, storm, drought, crop failure, plague, and war; the land is laid waste, its inhabitants exiled. A covenant (brit, or bris) in the Hebrew Bible is generally a treaty in which both parties, whether human or divine, agree to cooperate with one another, and to limit their behavior in certain ways. The archetypal symbol for the covenant between God and Abraham, and therefore for Jews throughout history, is circumcision (Genesis 17:11) and the word for covenant and for circumcision is the same (bris). Whereas a covenant among tribes or nations may take the form of a social or political alliance, a covenant between people and God is in effect a reward for moral behavior: ${ }^{13}$ the natural world acts as a kind of bank from which rain is drawn in its

6. Franz Kafka, The Trial, trans. Wilma Muir and Edwin Muir (New York: A.A. Knopf, 1937).

7. Charles Dickens, Bleak House (London: Chapman \& Hall, 1853).

8. Henrik Ibsen, An Enemy of the People / En folkefiende [1882], trans. Christopher Hampton (London; Boston: Faber, 1997).

9. Friedrich Nietzsche, Thus Spoke Zarathustra / Also sprach Zarathustra [1885], trans. Graham Parkes (New York: Oxford University Press, 2015).

10. Thomas Hardy, Tess of the D'Urbervilles (New York: Harper \& Bros, 1892).

11. The Waste Land is included in The Poems of T.S. Eliot (2018).

12. A century after The Waste Land was written, most rivers in England are so polluted that they are dangerous to swim in or drink from. In a recent address to the British parliament, the naturalist, David Attenborough, spoke of plastics litter in the same breath as slavery - a form of human wickedness: Britain, originator of the Industrial Revolution, based on polluting coal, has a moral responsibility to fight the adverse effects of industry.

13. Certain forms of the word for covenant in the Hebrew Bible are used exclusively in treaties between God and man: "my covenant" (briti) or "his covenant" (brito). The many biblical Hebrew verbs used to describe the betrayal of a covenant - lehafer, le-chalel, le-chaper, li-m'os, le-na'er, la-avor, la-azov, le-shaker - suggests both frequency and distress. Most of these roots are Akkadian, which may indicate an origin in Mesopotamian law. Although the Hebrew Bible stresses the central moral role of God, particularly in defending the poor and vulnerable, pagan cultures, too, generally included moral teachings. Egypt is remembered in the Hebrew Bible as a "house of slavery" (Exodus 13: 13), yet some of the closest parallels to laws concerning the poor in the Hebrew Bible are found in Egyptian literature from the seventh to sixth centuryBCE, which warns against robbing the poor, the oppressed and disabled; against encroaching upon the property of the widow; and which recommends debt relief of two thirds and (as in the book of Ruth) tolerance for the widow gleaning in the field. See James B. Pritchard and Daniel E Fleming, The Ancient Near East: An Anthology of Texts and Pictures (Princeton, NJ: Princeton University Press, 2011), 246ff.; 352. Similarly, in Homer and Greek myth, the value of justice is often stressed. In the Greek legend of Deucalion as in Genesis, the gods are motivated by moral considerations in punishinghumankind. 
season and crops grow plentifully, and the thousand natural shocks to which life is prey are kept at a distance. To be in harmony with Nature is to be obedient to God. Human beings, though imperfect, should imitate divine moral attributes: "As He is merciful, so should you be merciful; as He is gracious, so should you be gracious; as $\mathrm{He}$ is righteous, so should you be righteous." ${ }^{14}$ When immorality breaks the covenant, Nature becomes the agent of divine retribution. The Hebrew Bible is a catalogue of repeated breaches of the covenant. In the chronological sequence from the beginning of Genesis to the end of Kings/Chronicles, the narrative backbone of the Hebrew Bible - from the exile from Eden to the exile from the kingdom human nature is laid bare in all its flaws.

And so, environmental abnormality in the Hebrew Bible follows moral failing, environmental pollution betrays moral pollution: the fire and brimstone, the drowning flood, the smoke and heat and sulphurous fumes of sin. ${ }^{15}$ Humanity has charge over the natural world - but with no entitlement to exploit or harm. ${ }^{16}$ Immoral behavior brings catastrophic earthquakes, floods, storms, fires, drought, wild beasts, and pestilence, and war above all. ${ }^{17}$ Those who abuse the earth they inhabit will be exiled - "vomited" by the earth. ${ }^{18}$ Humankind, though divinely created, is self-corrupted; open to insight, penitence, and selfcorrection, drawn to self-destruction. The originality of biblical sin stretches from casual disobedience to brutal child sacrifice in idolatrous practices, with stories and poems filled with human failings of all kinds, including incest, adultery, theft and murder. Human misbehavior literally scars the landscape, the earth does not erupt randomly under geological pressure, but under moral pressure; the skies do not open haphazardly with rainstorms flooding and destroying life, but with a punishing storm of moral judgment. The environment and morality are one - the ugly face of corruption. As rare as rainbows is loyalty to the moral covenant. Only Eden is divine, the earth given into human hands is the image of human frailty, of blood, sweat and tears. The covenant betrayed, a once-fruitful Eden withers into the landscape of the Cities of the Plain, "burnt stone and salt, a land unsowed, bare of plants and grass." 19

14. Louis Finkelstein, Sifra: A Commentary on the Book of Leviticus (New York: The Jewish Theological Seminary of America, 2014), see specifically Leviticus 19:2.

15. In stories in Genesis, earth and its environment are constantly changed for the worse through human behavior: With the eating of the forbidden fruit, "the land is cursed because of you...you will grow thorns and thistles" (3:17); of Cain when he murders his brother, Abel, "When you work the land, it will no longer give its produce" (4:12); in the story of Noah, the Flood is divine punishment for human wickedness (6:6-7); the Cities of the Plain are destroyed because of the evil deeds of their inhabitant (18:20), and Abraham watches the smoke of the inferno rising "like the smoke of a furnace" (19:28). The rainbow at the end of the story of Noah symbolizes the divine covenant: despite their ingrained evil, humans will not be punished with extinction (8:21-2).

16. The Creation story in the Hebrew Bible is generally understood in homiletic literature as an expression of reverence for Nature, the manifestation of divine will. However, the statement of fact, that humanity is empowered to 'conquer and rule' all living creatures (Genesis 1: 28: kivshuha u-redu), can be interpreted as a license to exploit the natural and the human destruction of the environment might be attributed partly at least to this understanding of the Hebrew Bible's meaning of the world. See Lynn White Jr., "The Historic Roots of Our Ecologic Crisis,” Science 155 (1967): 1203-1207 and David Horrell, The Bible and the Environment: Towards a Critical Ecological Biblical Theology (London: Routledge. Middlesex: Penguin Books, 2010). However, in no literary work depicting environmental degradation or ruin - e.g., Blake, Jerusalem;Goethe, Faust; Fyodor Dostoyevsky, Poor Folk; Elizabeth Gaskell, Mary Barton; Charles Dickens, Hard Times; Henrik Ibsen, An Enemy of the People; Anton Chekhov, Uncle Vanya; Upton Sinclair, The Jungle; John Steinbeck, The Grapes of Wrath; J.M. Coetzee, The Time and Times of Michael K. - is the actual content of the Hebrew Bible regarded as cause or justification for any form of willful destruction of the natural world. To the contrary, the Hebrew Bible stresses awe and joy in creation and the need for regulation through law, by which human beings treat one another and the world they share withjustice and fairness.

17. On environmental disaster in the Bible see David Aberbach, The Environment and Literature of Moral Dilemmas: From Adam to Michael K. (London and New York: Routledge, forthcoming 2021), specifically chapter 10.

18. Jeremiah 12:4; Leviticus 18:25.

19. Deuteronomy 29:22. 


\section{Ecology and Moral Disaster and Recovery in the Bible}

Two tales of moral failing in the Hebrew Bible have special meaning in the history of environmentalism: 1. in the account of the divine origin of creation in Genesis (Ch. 1-3), and the paradise lost by Adam and Eve; 2. in the story of how war, defeat and exile brought ecological collapse to the land of Israel: destruction of forests, vineyards and olive groves, land abandoned and left to ruin, cypress to thorn, myrtle to briar. ${ }^{20}$ The Hebrew Bible opens with the loss of Eden in Genesis and ends with the loss of the kingdom at the end of Chronicles. ${ }^{21}$ The chronological sequence of narratives linking these two events sets an ideal of justice and righteousness against a long charge sheet of crimes and misdemeanors. The morality of the Hebrew Bible, framed in universal ecological terms, identifies wrongdoing with exile from Eden and the destruction of the land. Human damage to the natural world is self-damage. Truth and social justice, the care of the poor and the downtrodden, create a new Eden. ${ }^{22}$

Hosea (eighth century BCE), the prophet who recounts the destruction of the Northern kingdom of Israel at the hands of the Assyrians, is among the earliest prophets to depict ecological ruin as a divinely ordained punishment for national betrayal of the covenant. The prophet, himself betrayed by his wife, a prostitute, felt that the entire nation had 'prostituted' itself through idolatry and immorality. The nation planted and reaped evil, and ate the fruit of adultery and theft, falsehood and injustice, blasphemy and bloodshed. The land went to ruin, its inhabitants dried up and vanished as totally as the morning mist or the early dew, as chaff from the threshing floor or smoke swirling through the window. Living things, birds, beasts and fish, were swept away; and the vines and fig trees, the fruitless harlot's hire, were devoured by wild animals. ${ }^{23}$

Scenes of wildfire in the Hebrew Bible are dramatized by the prophets as moral allegories of social disintegration, the land charred with divine wrath. Images of fire come from eyewitness experience in an agricultural world in which fire destroyed forests, crops, and entire communities ${ }^{24}$ especially as the great

20. After the destruction of the Temple in Jerusalem in 586 BCE, the survivors were exiled to Babylon, where they were used as slaves (2 Chronicles 36:20).

21. The structure of the Hebrew Bible in the Jewish canon - this comprises twenty-four books, assembled, preserved and edited by sofrim (scribes) and teachers over many generations - points to the sixth century BCE as a time when the idea of preserving Jewish religious culture and history had particular significance, to keep the nation alive in exile. The Hebrew Bible is edited in two parts: a long chronological sequence from the Creation to the Exile, spanning the Five Books of Moses, Joshua, Judges, Samuel, and Kings, to the mid sixth century BCE; and wisdom literature ending with the book of Chronicles which closes with the Edict of Return issued by Cyrus in 538 BCE. The Christian Bible loses the impact of the Hebrew Bible by shifting the books of Chronicles to follow the books of Kings; the editors of the Hebrew Bible intended it to end on a note of resounding national hope, with the return from exile to the land of Israel. There are later books, notably Esther,Daniel and Ecclesiastes, but the bulk of the editing seems to have been done earlier. The final canon was not decided until after the destruction of the Second Temple in 70 CE. Public readings from parts of what became the Hebrew Bible evidentlybegan in the late sixth century BCE (as can be seen in Nehemiah 9) and these texts, whatever their origin, were now lookedupon as sacred.

22. Milton, in Paradise Lost (xii. 581-587), identifies moral behavior as the means to recreate Eden. See John Milton, 16081674, Paradise Lost (London: Penguin Books, 2000).

23. Hosea $2: 12 ; 4: 2-3 ; 13: 3,15$.

24. At the heart of the Babylonian Epic of Gilgamesh is the moral taint of deforestation, presented as a crime against Nature. See N. K. Sandars, The Epic of Gilgamesh: An English Version, With an Introduction, Rev. ed. (Harmondsworth; New York: Penguin, 1972). In the Hebrew Bible, imagery of the forest fire appears in the story of Jotham after his seventy brothers are murdered by Abimelech; he tells the parable of the trees seeking a king who go to the worthless incendiary thornbush, capable of destroying the state: "The thornbush said to the trees, 'If you really want to anoint me king over you, come and take refuge in my shade; but if not, then let fire come out of the thornbush and consume the cedars of Lebanon!'” (Judges 9:15). Compare Revelation 8:7, in which one-third of the trees on earth are burned. The story of Samson illustrates the ease with which determined arsonists could (and still do) operate, with fire in a parched environment. He ties the tails of three 
empires invaded country after country in the Fertile Crescent, bringing terror, violence, grief, and smouldering ruins. ${ }^{25}$ The prophets saw fire as punishment. In the book of Isaiah, fire executes God's wrathful judgement. ${ }^{26}$ Ezekiel prophesies to the forest its impending destruction as part of the divine punishment of the kingdom of Judah by Babylonia: "I will set you on fire and destroy all your trees, green and dry. The blazing flame will not be quenched, every face from south to north will be scorched by it." 27 In the conflagration of evil, Judah's enemies, too, will be destroyed "as fire consumes the forest or a flame sets the mountains ablaze." 28 Plague was also the execution of divine will:

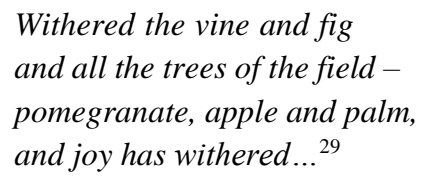

Earthquakes in the land of Israel could cause huge devastation and were generally seen by prophets such as Amos (1: 1), Isaiah (6: 4), Joel (3: 16), and Zachariah (14: 5) - as are similarly destructive "acts of God" to the present day - as a call to faith. The prophet Ezekiel lists four punishments for the sins of Israel - sword, famine, wild beasts, and pestilence (14: 21), which appear a half-millennium later, in Revelation (6: 1-8), as the "four horsemen of the apocalypse." 30 The prophet Jeremiah writes similarly of human evil as a cause of ecological ruin. The stricken land mourns:

How long will this land mourn, and grass die everywhere, birds and beasts die, for the evil of these men. ${ }^{31}$

In the Psalms, too, moral erosion leads to the erosion of the earth:

He turned rivers to desert,
Flowing Springs to a land of thirst

hundred foxes in pairs, attaches a lighted torch to each pair, and lets them loose in the Philistine fields, destroying their corn, vines, and olive trees (Judges 15:4). Fires in the Middle East in any case easily break out accidentally (Exodus 22:6). 25. On prophetic literature in response to imperial conquest in the ancient near east see David Aberbach, Imperialism and Biblical Prophecy 750-500 BCE (London and New York: Routledge, 1993). Modern war literature tends to follow the Hebrew Bible in depicting the ruin of the landscape as symbolic of human failings. Ernest Hemingway, in $A$ Farewell to Arms is set on the Italian front of World War I and describes the impact of the war on the forests: "The forest of oak trees on the mountain beyond the town [Gorizia, in northern Italy] was gone. The forest had been green in the summer when we had come into the town but now there were the stumps and the broken trunks and the ground torn up..." Ernest Hemingway, A farewell to Arms (New York: Scribner, 1929), Ch. 2. D.H. Lawrence, in Lady Chatterley's Lover, uses imagery of cutdown trees to describe the war-wounded Clifford Chatterley, a physical and emotional cripple, See David Herbert Lawrence, 1885-1930. Lady Chatterley's Lover (New York: Grove Press, 1959).

26. Isaiah 66:16-17. In Jewish liturgy this passage is read on the New Moon which falls on the Sabbath.

27. Ezekiel 20:47.

28. Psalms 83:14.

29. Joel 1:12. This passage, in the King James translation, is quoted by Thoreau at the end of his essay, "Wild Apples": "The vine is dried up, and the fig-tree languisheth; the pomegranate tree, the palm-tree also, and the apple-tree, even all the trees of the field, are withered: because joy is withered away from the sons of men." Henry David Thoreau, "Wild Apples," The Atlantic Monthly, November 1862.

30. For a scientific retelling of ancient myths such as those in the Hebrew Bible, see Richard Dawkins, The Magic of Reality: How We Know What's Really True (London: Bantam Press, 2011).

31. Jeremiah 12:4. 
fruitful land to a salty waste, for the wickedness of its inhabitants. ${ }^{32}$

As immorality causes exile and ecological ruin, moral behavior brings return and ecological renewal: reforestation, rivers flowing in formerly dry land, with newly planted cedars, acacias, myrtles, olive trees, cypresses, plane trees and pines. ${ }^{33}$ The prophet Hosea gives hope of renewal, in language of ecological restoration. Divine compassion is certain as the sunrise or the rain in winter and spring; righteousness will be planted; the fruit of love will grow:

I will be as dew to Israel, he will blossom like a lily,

like a cedar of Lebanon he will send his roots and shoots,

splendid as an olive tree, fragrant as a cedar of Lebanon;

his people will live again in his shade, flourish like the grain,

blossom like the vine-

Israel will be famous as Lebanon wine... ${ }^{34}$

Jeremiah, too, prophesies the return of the exiles of the destroyed kingdom of Israel as an ecological rebirth, a river-like flow bringing back the fertile earth, with abundant corn, wine and oil, sheep and cattle, as well as spiritual fertility: "their soul will be like a watered garden." 35 Ezekiel foresees a time when a freshwater river will run from the Temple in Jerusalem through the wilderness of Judah into the Dead Sea valley, the lowest, driest, saltiest, and deadest place on earth, bringing it to life, filling it with fish, making the entire region green with trees and plants. ${ }^{36}$ The desolate mountains of Israel will have new fertility when the people return from exile:

... your trees will grow and give fruit

for my people Israel,

and you will be tilled and sown...

and the cities will be inhabited

and ruins rebuilt... ${ }^{37}$

Isaiah, similarly, prophesies that after a period of grief for the ruin of the land, the divine spirit will again descend upon humanity:

Then justice will be in dry land

and righteousness as the Carmel-

32. Psalms 107:33.

33. On desert transformed to fertile land, see Ezekiel 47: 1-12; Isaiah 35:1, 6; 41:19; 43: 19; 44:3; and Psalms 107:35. The fall and exile of the Northern kingdom of Israel is described in imagery of tree-felling in Isaiah 9:9, while the messianic age is conceived in imagery of deforestation in the destruction of the Assyrian empire in Isaiah 10:33-34 and the growth of a tree of salvation, which are passages read together on the eighth day of Passover: "a shoot shall come from the stock of Jesse, and a twig from his roots" (Isaiah 11:1; also see Zachariah 3:8).

34. Hosea 14:6-8.

35. Jeremiah 31:12. This passage is read on the second day of the Jewish New Year. The same Hebrew phrase for "watered garden," gan raveh, appears in Isaiah 58:11, again in the context of reward for righteous behavior, and read on the Day of Atonement.

36. Ezekiel 47: 1-12. Similar prophecies are made by Joel and Zachariah. Joel 4:18 foresees a time when dry riverbeds will fill with rushing waters and a fountain will flow from the Temple in Jerusalem to the wadi of acacias (nahal ha-shittim). Zachariah 14:8 predicts a day when living streams will flow from Jerusalem to the Dead Sea and the Mediterranean, winter and summer. Also see Revelations 22:1-2.

37. Ezekiel 36:8-10. 
the fruit of eternal peace...

the desert will rejoice and blossom like a rose...

waters will burst into the wilderness... ${ }^{38}$

In the Psalms, too, exile and return are part of a natural cycle, of sowing and harvest, and winter rain in dry land:

\author{
Bring back all our captives, O Lord! \\ like the desert streams! \\ Who sow in tears shall reap in joy! \\ Who go out weeping, scattering seeds, \\ shall come back singing, sheaves in arms! ${ }^{39}$
}

\title{
The Bible and the Romantics
}

In modern literature, environmental issues as a major concern begin with the Industrial Revolution. Poets of the Romantic movement such as Blake, Wordsworth, and Goethe were troubled by the effects of industry and capitalism, particularly as they exploit the poor and damage their lives. The Romantics follow the Bible in seeing Nature as a source of moral good, vulnerable to ruin at human hands. Poets were among the first to protest the catastrophic impact of modern industry on the environment and may be counted among the early conservationists. Blake, inspired by the revolutionary dissent of Hebrew prophets such as Isaiah and Ezekiel and their visions of a new Jerusalem and a new Eden, is outraged by the deterioration of the urban environment caused by industry, and by the injustice to the poor. The poet, a Londoner, denounces the evil of the streets of London and the Thames, he laments the fear and woe of its inhabitants, their disease and weakness, the "chimney-sweeper's cry" and "youthful harlot's curse" (1791) ${ }^{40}$ Yet, for a visionary Blake had an intensely real and practical view of what was wrong. From the polluted hell of the city, the countryside with clean air and water, and fruitfulness, was still in sight, in the rolling meadows, hills, brooks and woods, soon to become part of north London. ${ }^{41}$ As revolution spread, and succeeded, across the Channel and across the Atlantic, Blake took up the cause of revolutionaries such as Thomas Paine. Existing governments, monarchies, and aristocrats, he says, are frauds and impositions on the poor. They are mad and stupid to build palaces and courts, and wage wars with money which could be better spent on welfare and education for the poor. In Jerusalem (1804), ${ }^{42}$ Blake attacks the slavery and filth of English industry, blighting the lives of the young, near his home in Lambeth, making the "arts of life" into the "arts of death":

38. Isaiah 32:15-17; 35:1, 6. For similar images of water transforming the wilderness, see Isaiah 43:19; 44:3 and Psalms 107: 35 . Ezekiel's prophecy is that the Dead Sea valley, site of the earthquake which destroyed the Cities of the Plain, will return to being as it was beforehand, an Eden, "a garden of the Lord" (Genesis 13:10). Such fantasies are not uncommon in literature. Among the extravagant dreams of Peer Gynt in Henrik Ibsen's play, An Enemy of the People, is to build a canal from the sea to the Sahara and make it bloom.

39. Psalms 126:4-6.

40. William Blake, "London," in The Complete Poetry and Prose of William Blake, ed. D. Erdman, commentary by H. Bloom (Berkeley, California: University of California Press, 1982), 2.

41. Hogarth's painting The March to Finchley (1750), a view of London looking north of Tottenham Court Road, shows countryside where the Euston and Kings Cross rail terminals are now, the hills of Hampstead and Highgate in the distance. To Blake, Primrose Hill was a rural beauty spot: "I have conversed with the spiritual sun. I saw him on Primrose Hill." Blake's contrast between the city, environmentally and morally polluted, and the countryside, clean and pure and closer to Eden, recalls similar contrasts in dystopian novels such as Orwell's 1984 and Bradbury's Fahrenheit 451.

42. William Blake, "Jerusalem," in The Complete Poetry and Prose of William Blake, ed. D. Erdman, commentary by H. Bloom (Berkeley, California: University of California Press, 1982), 7. 


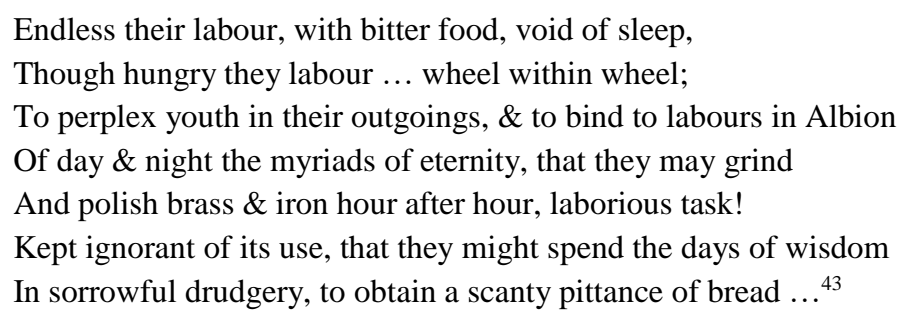

Alienation from the natural world pervades the poetry of Blake, who found in late eighteenth-century urban life, "Marks of weakness, marks of woe":

They know not why they love nor wherefore they sicken $\&$ die

Calling that Holy Love: which is Envy Revenge \& Cruelty

Which separated the stars from the mountains: the mountains from Man

And left Man, a little grovelling Root, outside of himself... ${ }^{44}$

To Blake, the chimney-sweep children of Songs of Innocence (1789) and Songs of Experience (1794) are the image of innocence in the evil world forcing them to wear "clothes of death" and to work toward their "coffins of black" in a dangerous, health-destroying profession. ${ }^{45}$ Most sweeps, often illegitimate or orphaned and apprenticed by the local parish, or sold by impoverished parents unable to feed them, were dead by age twenty. Blake condemns human nature as evil: cruel, jealous, frightened, secretive. In 1798, amid worsening conditions of war and scarcity, the clergyman Thomas Malthus published Essay on Population, ${ }^{46}$ in which he argued that the environment could not sustain the current rate of population increase. The poor, rapidly increasing in numbers, were an impossible burden on society. Population control and stringent legislation were needed. Blake bitterly mocks Malthus in Vala, or The Four Zoas ${ }^{47}$ :

\footnotetext{
... when a man looks pale

With labour \& abstinence, say he looks healthy \& happy -

And when his children sicken, let them die. There are enough

Born, even too many, \& our earth will be overrun

Without these arts. ${ }^{48}$
}

Wordsworth, England's leading Nature poet, was outraged at the adverse effects of industry and fought - unfashionably and controversially in his day - to keep the railroad out of the Lake District and in doing so planting the seed for what would become the Lake District as a National Park. ${ }^{49}$ Wordsworth presents his childhood as a series of pure responses to Nature: the poet alone in a natural world untouched

43. Jerusalem 3, 59:30-1, 65:21-6. In Jerusalem, Blake articulates a sense of the worker's alienation from work, prophetic of Marx.

44. Blake, “Jerusalem,” 162. See Jerusalem, 17:29-32.

45. See D. Erdman, ed., The Complete Poetry and Prose of William Blake, commentary by H. Bloom (Berkeley, California: University of California Press, 1982).

46. Thomas Malthus, An Essay on the Principle of Population (London: Ward, Lock and Co., 1890).

47. See D. Erdman, ed., The Complete Poetry and Prose of William Blake, commentary by H. Bloom (Berkeley, California: University of California Press, 1982).

48. William Blake, "Night the Seventh," in The Complete Poetry and Prose of William Blake, ed. D. Erdman, commentary by H. Bloom (Berkeley, California: University of California Press, 1982), 118-122. Malthus might have been influenced by Homer's account of the origin of the Trojan war, in The Iliad: Zeus, king of the gods, creates the chain of events leading to the war in order to reduce the earth's population.

49. Juliet Barker, William Wordsworth: A Life in Letters (London: Penguin, 2007), 284. 
by industry, at night beneath the stars, clinging to the edge of cliffs in a high wind, robbing birds' nests of their eggs, in a stolen boat alone on Esthwaite water surrounded by accusing cliffs; these passages have the raw visual force of Turner who, to feel the power of Nature, had himself lashed to a spar on a storm- tossed boat, or the musical force of the dying Beethoven raging against the heavens in a storm. Wordsworth's landscape is an English landscape as Turner's boat is an English boat, and Beethoven's music is German, but the feeling is for Nature, universal, all-powerful, eternal.

Wordsworth was appalled at the sufferings of the poor as industry destroyed their local agricultural and cottage economy that had sustained them for generations, driving them from small country villages into a new kind of mass impoverishment in the cities. Wordsworth, a mathematics student at Cambridge and an admirer of Newton, could see the possibility of a fruitful relationship between science and poetry, ${ }^{50}$ but in his lifetime science was increasingly a force of destruction. In the poem, Michael (1800), ${ }^{51}$ Wordsworth laments the end of a centuries-old way of life amid a landscape of unspoiled God-given beauty and the start of a city-dominated life as much morally as environmentally polluted. To Wordsworth, Nature the great healer is ravaged by the diseases of Industry:

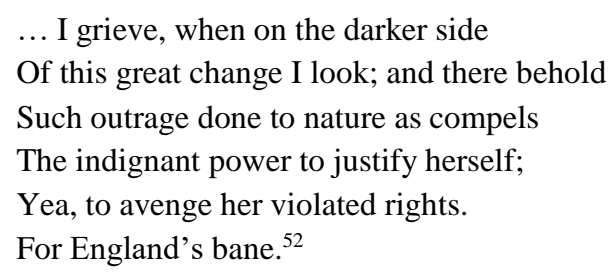

In The Excursion (1814), men build factories as pagan temples to the god of Gain:

50. In the Preface to the Lyrical Ballads, Wordsworth writes of science as a fitting subject for poetry, see William Wordsworth, Lyrical Ballads. 2nd ed. (New York: Columbia University Press, 1800) and in The Prelude science and poetry are joined in the fable of the half-crazed solitary Arab Quixote in the desert who holds the stone of mathematics and the shell of poetry; in the latter is heard a prophecy of "Destruction to the children of the earth, / By deluge, now at hand" see William Wordsworth, The Prelude of 1805, in Thirteen Books (World Public Library: DjVu Editions Classic Literature, 1805), 98-99. In The Prelude (1850 edition), Wordsworth recalled the impression of Newton's statue at Cambridge:

And from my pillow, looking forth by light

Of moon or favouring stars, I could behold

The antechapel where the statue stood

Of Newton with his prism and silent face,

The marble index of a mind for ever

Voyaging through strange seas of Thought, alone.

See William Wordsworth, The Prelude, or Growth of a Poet's Mind: an autobiographical poem (Edward Moxon, 1850), 58; 63.

51. Barker, William Wordsworth.

52. Barker, William Wordsworth. See The Excursion (viii 150-5). Other poets, including Crabbe and Clare, were similarly outraged. On Clare's poetry and the changing environment in which he wrote in the North of England, see Jonathan Bate, John Clare: A Biography (London: Picador, 2003). Wordsworth, unusually for his time, was critical of hunting, in "HartLeap Well” (1800): “This beast not unobserv'd by Nature fell / His death was mourn'd by sympathy divine.” Melville's Moby Dick (1851), in its portrayal of Captain Ahab, the half-crazed whale hunter, can be read as a critique of obsessive human destruction of irreplaceable natural resources. To a certain poetic eye, however, even the bleakest industrial images have their beauty, as in John Masefield's "Cargoes," despite its implied criticism of the grubbiness of modern imperial trade "Dirty British coaster with a salt-caked smoke stack / Butting through the Channel in the mad March days, / With a cargo of Tyne coal / Road-tail, pig-lead, / Firewood, iron-ware, and cheap tin trays"; or Auden's "Letter to Lord Byron" (1936): "Tramlines and slagheaps, pieces of machinery, / That was, and still is, my ideal scenery." Both poets, however, lived apart from the scenery they describe, comfortably in the countryside. 


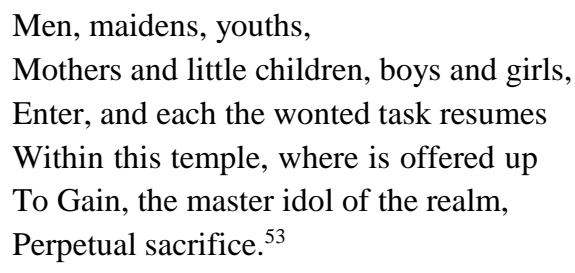

Wordsworth's older contemporary, Goethe, of all poets perhaps the most economically minded - he was Minister of Finance at Weimar at a time of rapidly-growing European industry in the early nineteenth century - warned that the lust for gain could cause destruction of the natural world and of people's lives. As Blake did in Jerusalem, and Marx in Kapital, he also protested increased work specialization in industry - this insulted human nature, which gravitated to diversity, and alienated the individual. Blake saw the explosive apocalyptic force of the Industrial Revolution, its new forms of harnessing and exploitation of Nature, as an age-old expression of energy, sin, enterprise, and creativity; Goethe's Faust ${ }^{54}$ wields similarly destructive forces, allied literally with the Devil. ${ }^{55}$ Goethe shared with his contemporary, Shelley, the belief that poets changed society; and he believed, too, that science derived from poetry. Faust, Part Two $(1829)^{56}$ expresses sorrow for the damage done both to the natural world and human nature. Faust's sick ambition is to seek happiness not in Gretchen, whom he abuses, but in draining swampland. And so, failing to drain his own spiritual swamp, he abandons desire and need for love for illusory ambition, the quest for dominion and control of Nature. Faust, a template for humanity, defaces the landscape, ruins his life and the lives of others, and loses all: security, joy, and beauty. ${ }^{57}$

\section{The Environment and "Condition of England" Novelists}

Nineteenth century English novelists, though mostly indifferent to theological dogma, tended to view environmental problems of their time as a betrayal of religious ideals. Charles Dickens (1812-1870) saw the increasing numbers of the rural poor working in factories -he himself had been a factory worker

53. William Wordsworth, The Excursion (London: Longman, Hurst, Rees, Orme, and Brown, 1814). Quotation taken from Barker, William Wordsworth The Excursion viii, 184-89. In Zola's Germinal, similarly, the dragon of industry consumes its sacrifices, the workers, see Émile Zola, Germinal, trans. Peter Collier (Oxford: Oxford University Press, 1998).

54. Johann Wolfgang von Goethe, Faust: A Tragedy, trans. M. Greenberg (New Haven and London: Yale University Press, 2014).

55. The notion that the damage done by capitalism is a necessary evil for the greater good has pre-modern antecedents embedded in religious tradition; the language of the "sinful good" of capitalism is strikingly similar to that of Lurianic kabbalah, by which "there is no evil that does not contain an element of good, nor is there a good entirely free of evil" Isidore Epstein, Judaism: A Historical Presentation (Harmondsworth: Penguin Books, 1959), 245. Keynes acknowledges in The General Theory of Employment, Interest and Money (1936) that he took from Mandeville the idea that society is driven by vice, see John Maynard Keynes, The General Theory of Employment, Interest and Money (Houndmills: Palgrave Macmillan for the Royal Economic Society 2007), 359ff. The evil involved in capitalism, in Keynes's view, is unavoidable: capitalism, for example, stimulates industry which causes environmental pollution, but it also generates taxes to pay for welfare and environmental research. The biblical idea of the yetzer ha-ra (evil inclination), starting from Adam and Eve is central in rabbinic literature; a rabbinic image for "necessary evil" of the yetzer ha-ra as the active ingredient in human motivation and action is "the yeast in the dough." Kabbalah expands the imagery of yetzer ha-ra in its conception of aliyah tzorekh yeridah, ascent to holiness requiring descent to sin; of a world of shattered vessels whose scattered sparks of holiness (nitzotzot) must be gathered and made whole once again.

56. John Gearey, "Faust II and the Darwinian Revolution," in Johann Wolfgang von Goethe, ed. H. Bloom (Philadelphia: Chelsea, 2003).

57. The critique of capitalism in Faust is taken up by Wagner in the Ring cycle, in which the dwarf Alberich renounces love and devotes his life to material gain. 
at age ten - as a moral blot. Legislative reform was disillusioning in that it did not go far enough. The Reform Act of 1832 shifted power from the aristocracy to the employers, concerned mainly with profit, not workers' health and welfare. England was spared the Continent-wide revolutions of 1848-1849, but was endangered by the enormous gap - exposed for the first time in detailed government statistics - between its wealth and the deteriorating conditions of its poor: their heavily polluted environment and poor sanitation, malnutrition, sickness, low life expectancy, high childhood mortality rates, inferior educational opportunities and life chances. London was a foggy disease-ridden "landscape of filth and destruction," with open sewers and children dying of hunger. ${ }^{58}$ Dickens' fictional Coketown in Hard Times (1854), a typical smoky industrial town in the north of England, exemplifies all that is wrong with industrial cities and capitalism: greed, heartlessness, and exploitation of the poor; a tendency to see workers not as people but as slave-like "operatives" to be paid so much and worked so much, and whose poverty is their own fault; the pollution, ugliness, and uniformity, and the sheer heart-breaking struggle of their lives. The river running through Coketown is purple with dye from the factories - the color of sin in Isaiah 1: 18 - its buildings black with soot, its streets all grimily alike; and a corresponding educational smog destroys individuality and the imagination. ${ }^{59}$ Clear days are rare. The foggy, hazy air and murky water mirror the moral muddle by which large numbers of people work themselves to death to make their employers rich. The industrialists see their employees as "something wholesale, of which vast fortunes were made," not much different than the "animated tools" in the ancient Greek slave system. ${ }^{60}$ Factory owners resist reform, claiming that change would deprive them of profits. They are largely unconcerned with the ruin their factories bring to the lives of their workers. Parliament passed laws to limit the damage they caused; but their main concern was their own "ruin". ${ }^{1}$

At the time Hard Times was first published, in 1854, perceptions of poverty and the poor were changing radically. Neither Dickens nor his contemporaries (including Marx) foresaw the extent of change for the better brought by the Industrial Revolution coupled with improvements in sanitation, hygiene, and medicine. Nor did Dickens appreciate fully that statistics ("Facts, sir; nothing but Facts") could and did give unanswerable arguments for social reform. ${ }^{62}$ Literature became a public voice for the poor, heard by legislators. As workers' conditions and the plight of the poor entered the literary mainstream, the urban en-

58. Peter Ackroyd, Dickens (London: Minerva, 1993), 406. On the extraordinary improvements in public health in nineteenth century London, when its population rose from one to six million, see Lee Jackson, Dirty Old London: The Victorian Fight against Filth (New Haven and London: Yale University Press, 2014). On changes in English society brought about by parliamentary reform, and reflected in its culture, see David Cannadine, Victorious Century: The United Kingdom, 18001906 (London: Penguin Random House, 2017). Illustrating the growing literacy among the working class, and a growing market for Condition of England novels, is the fact that in 1839, the Chartist Northern Star had a weekly circulation of over 60,000. See E.J. Hobsbawm, The Age of Revolution 1789-1848 (New York: New American Library, 1962$), 157$.

59. Compare Gaskell's description of Manchester in chapter five of Mary Barton (1848), with its endless identical streets, the dust giving everything "a dark shade of Indian ink." In contrast with the mid-nineteenth century world of uncontrolled industrial pollution in Hard Times, Tsarist Russia was slow to industrialize, an environmental advantage which it steadily lost in the latter half of the century. For a literary portrait of the pollution of a small Russian town in the late nineteenth century, similar to Coketown in Hard Times, see Chekhov's story In the Ravine (1897).

60. Hard Times, Book 2, Ch. 6. Compare Steinbeck in chapter nineteen of The Grapes of Wrath: "crop failure, drought, and flood were no longer little deaths within life, but simple losses of money." Dickens' horror at the effects of industry was largely determined in childhood when, after his father's imprisonment in a debtors' prison in 1822, he was sent to work, aged ten, in a London factory, a nightmarish episode described in David Copperfield.

61. Hard Times, Book 2, Ch. 1. In An Enemy of the People, Ibsen depicts a town in which the townspeople are more concerned with the possibility of their financial ruin than with the spread of death and disease caused by their factories.

62. Dickens' polarization of Fancy and Fact, heart and head, compassion and calculation, in chapter thirty-seven of Hard Times, might have been influenced in part by Gaskell's Mary Barton, particularly the moral summing-up by the old Manchester laborer, Job Legh: "them that is strong in any of God's gifts is meant to help the weak - be hanged to the facts!" 
vironment became central in political debate. Poverty in Victorian England was a more pressing issue, in legislation as in literature, than at any time previously, in any country.

Among nineteenth century novelists, Elizabeth Gaskell had an exceptionally clear view of environmental degradation in the lives of the poor. As a minister's wife in Manchester, she often visited her poor fellow-parishioners and was shocked by what she saw. She describes their lives in almostnauseating detail in her novel Mary Barton (1848) ${ }^{63}$ Having recently lost a child of her own, she was appalled to find that her tragedy was practically the norm among the poor; and this too enters her novel as a motive for murder. Gaskell and Charles Kingsley follow Dickens in their critique of slum conditions and unrest in the industrial city. Both saw the "condition of England" from a Christian viewpoint, Kingsley as a minister in the Church of England, rector of Eversley, Hampshire. Gaskell was well-placed to observe the mutual antagonism of capital and labor. Her Unitarianism drew her to a life of service to the poor, but her social position brought her into close contact also with wealthy industrialists who worshipped in her husband's church. Manchester factory workers had unusually high mortality rates. ${ }^{64}$

In Mary Barton, Gaskell depicts the stunted lives of exploited factory workers against the carefree luxurious lives of those who live parasitically on their labor. Though the two classes are dependent on one another, the rich and the poor live lives of dangerous alienation from each other, and the rich have little understanding of the lives of the poor. Gaskell takes us down a typical Manchester street filled with human waste and garbage, into a dark cellar in which an entire family lives: "The window panes are broken and stuffed with rags, the smell is enough to knock one down, several children are rolling hungrily in the dark on the damp floor, and their mother weeps in helplessness." ${ }^{65}$ John Barton, a Chartist leader who has seen his movement crushed, conceives a murderous hatred of the Poor Law system which allows such conditions to continue: "Damn their charity and their money!" ${ }^{66}$ Barton is sorely tormented by the vast wealth of the factory owners at a time when laboring people and their children (including Barton's own child) die of sickness and hunger. In an act of revenge, he murders the son of a factory owner. It is of great social and psychological interest that Gaskell's sympathies lie primarily with John Barton - despite his being a murderer: he is "sadly put about to make great riches and great poverty square with Christ's Gospel." ${ }^{\circ 7}$ Gaskell attributes the sharp rise in prostitution in the 1840 to workers' living conditions; ${ }^{68}$ and, in her Preface of October 1848, suggests that the continent-wide revolutions of 1848 stemmed from the injustice done to workers. Her views, though not revolutionary, are not far from those of Marx and Engels (himself a Manchester factory owner) in the Communist Manifesto (1848), published in the same year as Mary

63. Jenny Uglow, Elizabeth Gaskell: A Habit of Stories (London and Boston: Faber \& Faber, 1993).

64. Hans-Joachin Voth, "Living Standards and the Urban Environment," in The Cambridge Economic History of Modern Britain. Vol. 1., ed. R. Floud and P. Johnson (Cambridge: Cambridge University Press, 2004), 284. At the time Mary Barton is set, around 1840, life expectancy in Manchester was under thirty. On Gaskell's use of her own experiences and observations of the poor in her fiction, see Uglow, Elizabeth Gaskell.

65. Gaskell, Mary Barton, Ch. 6. Like many others, Gaskell sees the atrocious sanitation among the poor as inseparable from hunger, overcrowding and disease. Mary Barton is closely connected to the work of men such as Edwin Chadwick and John Snow, who brought about wide-ranging reforms in public health.

66. Gaskell, Mary Barton, Ch. 10, Gaskell's Mary Barton is set in 1839-1842, at a time of initial high hopes of Parliament and consequent disillusionment and despair as it became clear that Parliament mainly represented the interests of the middle and upper classes, and the "economic laws" that benefited these classes and seemed indifferent to the sufferings of the working-class poor. The alienation and rage of the poor was stoked by the feeling that legislators, magistrates, employers, even ministers of religion, were "their oppressors and enemies; and were in league for their prostration and enthralment" Gaskell, Mary Barton, Ch. 8.

67. Gaskell, Mary Barton, Ch. 37.

68. Gaskell shared with Dickens a commitment to helping "fallen women", Gaskell as wife of a prominent clergyman, Dickens as administrator of a home for such women in London; and prostitutes in their fiction (e.g., Nancy in Oliver Twist and Esther in Mary Barton) are presented with much sympathy. 
Barton. Gaskell constantly observes striking inequalities in the lives of the rich and the poor: thecomfortable houses and good food and warmth, the luxuries and leisure and superfluities of the rich, attended by their servants; the damp fetid cellars of the diseased and starving poor. In slack times, the richcut back on salmon and flowers; the poor on bread and coal. Gaskell writes with empathy of the rage against the rich and the desire for revenge. She dispels any illusion that the workers and factory owners are fellowcapitalists sharing the risk: the power is all on one side; market fluctuations make life a lottery for the poor; when a worker loses his job, he cannot feed his family and pay the rent; the owners risk capital; the workers risk lives. The rich abandon the compassion of the Gospels and use economic "law" to persecute the poor with the relentlessness of the Furies in the Eumenides. ${ }^{69}$ A Manchester song quoted by Gaskell describes the ignorance of the rich man about the poor: "He never heard the maddening cry, / Daddy, a bit of bread!" The poor watch their children die of hunger, the rich do not: "Han they ever seen a child o' their'n die for want o' food?" 70

Kingsley's novel Alton Locke: Tailor and Poet (1850) dates from the same period as Mary Barton and describes similar shock at workers' conditions, and it too, sets Christian ideals against a brutal reality. For Kingsley, the novel extended his clerical role. Alton Locke, like Mary Barton, appeared at the nadir of workers' fortunes in England, when industrial growth and population increase had not yet brought about real improvement in conditions. Yet, the outrage in both novels represents a significant change. Gaskell and Kingsley describe overcrowding, hunger, high infant mortality, poor education and life chances; but these had always been the conditions of the poor. An entire literature, created by some of the best nineteenth century writers, was now devoted to the poor, with the aim of reform. ${ }^{71}$ Kingsley wrote Alton Locke at thetime when Dr. John Snow started a revolution in public health by showing the connection between cholera and contaminated water, and famously broke the pump in Broad Street, Soho, in the 1854 epidemic. ${ }^{72}$ No one reading Alton Locke, published four years before this breakthrough, could doubt that dirty water spread disease. The growing recognition that science could prevent deaths created a moral panic. Alton Locke is one of the first novels to express anger at polluted water as a health hazard. The London tailor Jeremy Downes is furious that his wife and children have been poisoned by the open sewer running through their home. He would like to drown his sorrows with gin but is given the tactless advice that water is better:

\footnotetext{
Curse you and your water! If you had had no water to drink or wash with for two years but that - that, pointing to the foul ditch below - if you had emptied the slops in there with one hand, and filled your kettle with the other

Do you actually mean that that sewer is your only drinking water?

Where else can we get any? Everybody drinks it ... ${ }^{73}$
}

69. Gaskell, Mary Barton, Ch. 18. Gaskell's image of the avenging Furies to describe Christian charity is borrowed by Dickens in Our Mutual Friend (1856) Book 1, Ch. 8, to explain Betty Higden's refusal to fall into the vise of Charity: "It is a remarkable Christian improvement, to have made a pursuing fury of the Good Samaritan."

70. Gaskell, Mary Barton, Ch. 6.

71. In the Victorian era, sympathy for the poor began to enter children's literature: the hero of Kingsley's The Water Babies (1863) is a chimney sweep.

72. On the history of sanitation in London, see Jackson, Dirty Old London.

73. Charles Kingsley, Alton Locke: Tailor and Poet, ed. Herbert van Thal (London: Cassell, 1967), Ch. 35. In his later novel, Yeast (London: MacMillan and Co., 1851), Ch. 13, Kingsley returns to the subject of water pollution, in country villages, where open drains run in front of the doors and stinking waste lies in the roads until the rain washes it away. Similarly, unsanitary conditions in Chicago c.1900 are described in Upton Sinclair's novel, The Jungle (1906). 


\section{Conclusion: The Environment, Nationalism and Misanthropy}

For reasons of length, I must stop here, and the reader interested in pursuing further the concerns of this article is referred to my forthcoming book, The Environment and Literature of Moral Dilemmas. Despite the weakening of religious authority in Western societies since the Age of Enlightenment and the French Revolution, literature tends to follow the Hebrew Bible in seeing moral dilemmas in environmental degradation. Writers responded critically to the Industrial Revolution, with a greatly enhanced focus upon the disastrous effects of industrialization on the poor. At the same time, as nationalism grew, literature portrayed nations in constant conflict with one another, stimulating industry and bringing both destruction and progress. ${ }^{74}$ Much literature since the Industrial Revolution contributes to the misanthropic tradition in which human nature is fundamentally wicked - has in fact, like Faust, made a pact with the Devil. Blake, Nietzsche, and Conrad are among those who confront the human heart of darkness.

In his Autobiography, Mark Twain summed up his view of man as the most malicious and detestable of animals, "below the rats, the grubs, the trichinae...the only creature that inflicts pain for sport, knowing it to be pain." ${ }^{75}$ In Beyond the Pleasure Principle (1920), ${ }^{76}$ after the slaughter of World War I, Freud concluded that human beings have an inbuilt "death instinct" which could destroy civilization, a view he developed further in Civilization and its Discontents (1930), ${ }^{77}$ in which man is seen as a savage beast whose violent instincts threaten civilization with disintegration. Camus, in The Plague, ${ }^{78}$ written under the impact of the Holocaust, uses the image of bubonic plague to convey the horror of human destructiveness, always latent even in quiet times. The historian Yehuda Bauer reminds us: "The horror of the Holocaust is not that it deviated from human norms; the horror is that it didn't."79 In Holocaust literature, there are countless cases of human beings tortured and killed for sport or treated in an otherwise demeaning manner. In Auschwitz, Primo Levi recounts, he once reached for an icicle to slake his thirst and was stopped by a guard. Why? (Warum), Levi asked. The reply: Here there is no "why" (Hier ist kein warum). Auschwitz, the total defacement of the human image, was also a total environmental ruin. ${ }^{80}$

Literature from the Bible to the present day tends not to regard the human species as a reliable guarantor of the natural world, yet rarely abandons hope and faith. In this respect, too, the biblical outlook is preserved, though not necessarily its theology and dogma.

74. On national poetry, with many examples, see David Aberbach, National Poetry, Empires and War (London and New York: Routledge, 2015).

75. Mark Twain, Autobiography. 2 vols. (New York: Harper \& Brothers Publishers, 1924), II, 7. I am grateful to David K. Goodin, who has drawn my attention to the similarity of Twain's view of bestial human nature to that of Schopenhauer in "On Human Nature."

76. Sigmund Freud, The Complete Psychological Works of Sigmund Freud, Volume XVIII (1920-1922): Beyond the Pleasure Principle, Group Psychology \& Other Works, trans. John Strachey (London: Hogarth Press, 1920), 7-64.

77. Sigmund Freud, The Standard Edition of the Complete Psychological Works of Sigmund Freud, Volume XXI (19271931): Civilization and its Discontents, trans. John Strachey (London: Hogarth Press, 1930), 59-145.

78. Albert Camus, The Plague, trans. S. Gilbert (Middlesex: Penguin Books, 1968).

79. Yehuda Bauer, Rethinking the Holocaust (New Haven: Yale University Press, 2001), 43.

80. See Primo Levi, If this is a Man, trans. S. Gilbert (London: Sphere Books, 1979), in the chapter entitled "A Good Day." 


\section{Bibliography}

Aberbach, David. Imperialism and Biblical Prophecy 750-500 BCE. London: Routledge, 1993.

—. "Trauma and Abstract Monotheism: Jewish Exile and Recovery in the Sixth Century BCE." Judaism 50, no. 2 (2001): 211-221.

—. National Poetry, Empires and War. London: Routledge, 2015.

- Literature and Poverty. London: Routledge, 2019.

- The Environment and Literature of Moral Dilemmas: from Adam to Michael K. London: Routledge, Forthcoming 2021.

Ackroyd, Peter. Dickens. London: Minerva, 1993.

Barker, Juliet. William Wordsworth: A Life in Letters. London: Penguin, 2007.

Bate, Jonathan. John Clare: A Biography. London: Picador, 2003.

Bauer, Yehuda. Rethinking the Holocaust. New Haven: Yale University Press, 2001.

Blake, William. The Complete Poetry and Prose of William Blake. Edited by D. Erdman, commentary by H. Bloom. Berkeley, California: University of California Press, 1982.

Brockliss, William. Homeric Imagery and the Natural Environment. Cambridge, MA: Harvard University Press, 2019.

Camus, Albert. The Plague / La Peste [1947]. Translated by S. Gilbert. Middlesex: Penguin Books, 1968.

Cannadine, David. Victorious Century: The United Kingdom, 1800-1906. London: Penguin Random House, 2017.

Dawkins, Richard. The Magic of Reality: How We Know What's Really True. London: Bantam Press, 2011.

Dickens, Charles. Hard Times. New York: Harper \& Bros., 1854.

—. Bleak House. London: Chapman \& Hall, 1853.

Eliot, T.S. The Poems of T.S. Eliot. Edited by C. Ricks and J. McCue. London: Faber \& Faber, 2018.

Epstein, Isidore. Judaism: A Historical Presentation. Harmondsworth: Penguin Books, 1959. 
Evelyn, John. Sylva or a discourse of forest trees [1664]. London: Doubleday, 2001.

Finkelstein, Louis. Sifra: A Commentary on the Book of Leviticus. The Jewish Theological Seminary of America, 2014.

Freud, Sigmund. The Complete Psychological Works of Sigmund Freud, Volume XVIII (1920-1922):

Beyond the Pleasure Principle, Group Psychology \& Other Works. Translated by John Strachey. London: Hogarth Press, 1920.

- The Standard Edition of the Complete Psychological Works of Sigmund Freud, Volume XXI(19271931): Civilization and its Discontents. Translated by John Strachey. London: Hogarth Press, 1930.

Gaskell, Elizabeth. Mary Barton. London: Chapman and Hall, 1848.

Gearey, John. "Faust II and the Darwinian Revolution.” In Johann Wolfgang von Goethe. Edited by H. Bloom. Philadelphia: Chelsea, 2003.

Goethe, Johann Wolfgang von. Faust: A Tragedy. Translated by M. Greenberg. New Haven and London: Yale University Press, 2014.

Hardy, Thomas. Tess of the D'Urbervilles. New York: Harper \& Bros, 1892.

Hemingway, Ernest. A Farewell to Arms [1929]. Harmondsworth, 1958.

Hobsbawm, E.J. The Age of Revolution 1789-1848. New York: New American Library, 1962.

Horrell, David. The Bible and the Environment: Towards a Critical Ecological Biblical Theology. London: Routledge. Middlesex: Penguin Books, 2010.

Ibsen, Henrik. An Enemy of the People / En folkefiende [1882]. Translated by Christopher Hampton. London; Boston: Faber, 1997.

Jackson, Lee. Dirty Old London: The Victorian Fight against Filth. New Haven: Yale University Press, 2014.

Kafka, Franz. The Trial/ Der Process [1925]. Translated by Wilma Muir and Edwin Muir. New York: A.A. Knopf, 1937.

Keynes, John Maynard. The General Theory of Employment, Interest and Money [1936]. Houndmills: Palgrave Macmillan for the Royal Economic Society, 2007.

Kingsley, Charles. Alton Locke: Tailor and Poet [1850]. Edited by Herbert van Thal. London: Cassell, 1967. 
—. Yeast [1851]. London: Dent; New York: Dutton, 1976.

Lawrence, D.H. Lady Chatterley’s Lover. Harmondsworth, Middlesex: Penguin, 1960.

—. The Rainbow [1915]. New York: The Anchor Press, 1973.

Levi, Primo. If this is a Man / Se questo e un uomo [1947]. Translation by S. Gilbert. London: Sphere Books, 1979.

MacGregor, Geddes. A Literary History of the Bible: From the Middle Age to the Present Day. Nashville and New York: Abingdon Press, 1968.

Malthus, Thomas. An Essay on the Principle of Population. London: Ward, Lock and Co., 1890.

Milton, John. Paradise Lost. Edited by Alastair Fowler. Harlow: Longman, 2007.

Nietzsche, Friedrich. Thus Spoke Zarathustra / Also sprach Zarathustra [1885]. Translated by Graham Parkes. Oxford World Classics. New York: Oxford University Press, 2015.

Pritchard, James B, and Daniel E Fleming. The Ancient Near East: An Anthology of Texts and Pictures [1950]. Princeton, N.J.: Princeton University Press, 2011.

Sandars, N. K. The Epic of Gilgamesh: An English Version, With an Introduction. Revised Edition. Harmondsworth; New York: Penguin, 1972.

Shelley, Percy Bysshe. Defence of Poetry Hoboken. New Jersey: Bibliobytes, 1821.

Steinbeck, John. The Grapes of Wrath [1939]. New York: Penguin Books, 1997.

Thoreau, Henry David. "Wild Apples.” The Atlantic Monthly, November 1862.

Thoreau, Henry David, The Portable Thoreau. Revised Edition. Edited by Jeffrey S Cramer. London: Penguin Classics, 2012.

Twain, Mark. Autobiography. 2 vols. New York and London: Harper \& Brothers Publishers, 1924.

Virgil, The Eclogues / Eclogae [37-42 BCE]. Translated by Guy Lee. Harmondsworth, Middlesex: Penguin Classics, 1984.

Uglow, Jenny. Elizabeth Gaskell: A Habit of Stories. London and Boston: Faber \& Faber, 1993.

Voth, Hans-Joachin. "Living Standards and the Urban Environment." In The Cambridge Economic History of Modern Britain, vol. 1, 268-294. Edited by R. Floud and P. Johnson Cambridge: Cambridge University Press, 2004. 
White, Jr., Lynn. “The Historic Roots of Our Ecologic Crisis.” Science 155 (1967): 1203-1207.

Wordsworth, William. Lyrical Ballads. 2nd Edition. New York: Columbia University Press, 1800.

—. The Prelude of 1805, in Thirteen Books. World Public Library: DjVu Editions Classic Literature, 1805.

—. The Excursion. London: Longman, Hurst, Rees, Orme, and Brown, 1814.

The Prelude, or Growth of a Poet's Mind: an autobiographical poem. Edward Moxon, 1850.

Zola, Émile. Germinal [1885]s. Translated by Peter Collier. Oxford: Oxford University Press, 1998. 